\title{
Implementation of Performance-Based Budgeting: A Phenomenological Study on National Land Agency
}

\author{
Miftah Ruli Hartanto ${ }^{1}$, Busaini ${ }^{2}$, Animah ${ }^{3}$ \\ ${ }^{1}$ Land Office of Dompu Regency, Jl. Kakatua No.5 Dompu, West Nusa Tenggara Province, Indonesia. \\ e-mail: miftah.r.hartanto@gmail.com
}

${ }^{2}$ Accounting Master Program of Mataram University, Jl. Pendidikan No. 37 Mataram, West Nusa Tenggara Province, Indonesia e-mail: busainidr@gmail.com

${ }^{3}$ Accounting Master Program of Mataram University, Jl. Pendidikan No. 37 Mataram, West Nusa Tenggara

Province, Indonesia

e-mail: animahmtr@yahoo.co.id

\begin{abstract}
This study aims to describe the implementation of performance-based budgeting in the Regional Office of the National Land Agency of West Nusa Tenggara Province. This research was conducted by using qualitative research approach. The focus of research in this study is the implementation of performancebased budgeting in terms of budget planning, budget realization, performance evaluation, and reporting. The data used in this study include primary data and secondary data with data collection techniques such as observation, interview, and documentation study. The data in this research is analyzed using qualitative data analysis technique of interactive model from Miles and Huberman. The validity of the data obtained through triangulation test source. The results showed that in general, budget managers in the Regional Office of the National Land Agency of West Nusa Tenggara Province have understood the meaning of Performance Based Budgeting. However, so far they have not implemented Performance Based Budgeting properly because: (a) Unset and established strategic work unit level plan (b) frequent budget revisions due to incompatibility between annual work plans and actual circumstances (c) Control and evaluation system which is still weak (d) in terms of reporting performance only to meet formalities and administration.
\end{abstract}

Keywords: Performance Based Budgeting, Phenomenology, Planning

\section{Preliminary}

Good governance is the most prominent issue in the management of public administration today. Good governance is closely related to New Public Management (NPM). New Public Management is the most actual public administration management system in the world and is being realized in almost all developed countries. New Public Management is a global phenomenon, aimed at improving efficiency and effectiveness, enhancing responsiveness, and improving the managerial accountability of public organizations (Sancoko, 2008). Implementation of New Public Management in Indonesia begins with the reform in the financial sector with the birth of three packages of law, namely UU no. 17 / 2003 on State Finances, UU no. 1 / 2004 on State Treasury, and UU no. 15 / 2004 on the Audit of State Financial Management and Responsibility, has marked the start of a new era in the management of state finances. These three laws provide the basis for reform in the field of state finance, namely from financial administration to financial management (Solikin, 2006).

The budgeting approach used in the budgeting process includes approaches: Integrated Budgeting, Performance Based Budgeting (PBB), and Medium Term Expenditure Framework (MTEF). This budgeting 
approach becomes a reference for stakeholders in budgeting in designing and budgeting (Hesrini, 2015). In practice, the above three approaches focus more on PBB. The other two approaches (integrated budget and MTEF) support the implementation of PBB. An integrated budget approach is a prerequisite for implementing PBB. While the MTEF approach is a continuous guarantee of the provision of activity budgets because it has been designed up to three or five years into the future (Ministry of Finance of Republic of Indonesia, 2009)

Performance-Based Budgeting (PBB) is an approach in the budgeting system that takes into account the interrelationship between the funding and the expected performance, and takes into account the efficiency in achieving that performance. Performance is an achievement of work in the form of output from an activity or the outcome of a program with quantity and quality measured (Hesrini, 2015). Prior to the introduction of Performance-Based Budgeting system, the budgeting method used was the traditional method or line-item budget. The way this budget is drafted is not based on an analysis of the series of activities that must be linked to the stated objectives, but rather focuses on the need for expenditure and the system of accountability is not examined and examined whether the funds have been used effectively and efficiently or not. The benchmark for success is only demonstrated by the balance of budgets between income and expenditure but if the budget deficit or surplus means that the budget execution fails. In its development, there emerges a systematic performance budget defined as a form of budget whose sources are linked to the outcome of the ministry.

The performance-based budgeting approach is designed to try to overcome the weaknesses of traditional budgets, especially the weaknesses caused by the absence of benchmarks that can be used to measure performance in the achievement of public service objectives and targets (Haryanto, 2007). Budget with a performance approach emphasizes the concept of value for money and supervision of output performance, and is based on goals and performance goals. Therefore, the budget is used as a means to achieve the goal. Performance appraisal is based on the implementation of value for money and budget effectiveness (Mardiasmo, 2009: 84). Ineffective budget and not performance-oriented will be able to thwart the plans that have been prepared. Continuous performance measurements will provide feedback, so that continuous improvement efforts will be successful in the future (Bastian, 2006: 275).

Widyantoro (2009) said that the results of the Ministry of Finance's Finance and Education Agency (BPPK) study in 2008 stated that the Government of Indonesia has implemented Performance Based Budget but has not been intact and consistent. The implementation of the performance-based budget is reinforced by the 2009 Local Governance Support Program report in the DPRD's oversight of the Public Service which states that some performance accountability instruments are made unilaterally, such as the Government Agency Performance Report (LAKIP) tend to be just formalities and not reliable enough to assessing the performance of public organizations.

Implementation of performance-based budget that is still not perfect in Indonesia is also reinforced by the results of research conducted by Surianti and Dalimunthe (2015) who examine the implementation of performance-based budgeting in the public sector in Indonesia, the results show that the Indonesian government has been designed with the concept of performance-based budgeting that has been in accordance with the concept of performance-based budgeting and performance-based budgeting grand design in Indonesia show that this approach has been integrated into short, medium and long term planning. However, from various studies that have been conducted in Indonesia shows that performance-based budgeting is still 'rudimentary', ie only to meet formal legal, substantially no research results indicate that performance-based budgeting has been implemented in accordance with the basic concept that has been designed. The results of Surianti and Dalimunthe (2015) show that the 'failure' of the implementation of performance-based budgeting in ministry / agency institutions is mainly due to a lack of understanding of the basic concepts of budgeting based on performance by budget users and human resource issues in the Indonesian government sector The main problem.

The same results can also be seen from research conducted by Rahayu, et.al (2007) and Utomo (2007) with a qualitative approach to explore the understanding of the phenomenon of performance-based budgeting in local government. The results of the first study is the implementation of performance budgeting in the process of budgeting has not been running as desired. Policy changes are only followed by regions at the level of technical change and format, but paradigm shifts have not occurred much. A second study 
examines the implementation of performance-based budgeting at the North Luwu Forestry Office, South Sulawesi. The result of the research is the implementation of performance-based budget facing challenges such as data, human resources and mechanism.

The results of research and literature above are in line with those occurring in the Ministry of Agrarian Affairs and Spatial / National Land Agency (ATR / BPN). The implementation of performancebased budgeting at the ministry of ATR / BPN is still not perfect. As stated by Commission II of the House of Representatives (metrotvnews, 2016) that the Ministry of ATR / BPN has tried to realize the government's wishes according to Nawacita but in carrying out its duties are still many that have not been met according to target, for example from the target of certification of land ownership of transmigration land as many as 24 thousand fields, achieved 11 thousand fields or only $45 \%$ in 2015 . So also from the inventory of land ownership and use of land, of the target 143 thousand realization area only 69 thousand fields or equal to $48.76 \%$. Another example that is also highlighted by the House is the creation of a basic map scale of 1: 5000, the target 75 new locations reached 3 locations which means only realized 4\%. From the results of the review, Commission II of the House of Representatives concluded that there is no synchronization between the budget and the existing programs. This means that there is a problem in program planning or budgeting at the ministry of ATR / BPN.

In addition to the low physical realization, the House of Representatives also criticized the low budget absorption from the Ministry of ATR / BPN. When the Commission II of the House of Representatives held a hearing with the Director General of the Ministry of Agrarian and Spatial Planning to discuss various implementation of activities in 2015 and planning activities in 2016, members of the second commission rate that the budget absorption Ministry of Agrarian until the month of September only reached 38 percent. He said that the planning of the Ministry of Agrarian program is very good if at the top level. However, if the implementation is done by officials at the lower level, still far from the target (viva, 2015).

By the end of 2015 the Ministry of Administrative Reform and Bureaucracy Reform (KemenPANRB) has provided an assessment of the ministries and agencies regarding the accountability of the performance of government agencies. Assessment conducted since early 2015 against 77 Ministries / institutions. Explained that some of the indicators included in the assessment, namely the first is a performance planning that will be seen comprehensively or continuously. Performance planning includes Renstra, performance budgeting, and performance agreements. Assessment is made to the extent to which a government agency has made program plans that provide benefits or outcomes for the use of the allocated budget. Performance-based budgets mean that money exists after the planning is clear. The second is a performance measurement that illustrates the agency's performance benchmarks. Each agency must have a clear performance measure. Third is performance reporting, in which every government agency should be able to explain its performance within its budget to the community, stakeholders and other interested parties. Fourth is an internal performance evaluation that includes efforts to identify constraints and formulate comprehensive improvements. And the Fifth is performance performance. Performance achievement is an outcome generated and must be accountable. So government agencies should be results oriented, not just processes (menpan, 2015).

The results of the performance accountability assessment of government agencies by KemenPANRB that ranked first is the Ministry of Finance with a value of 83.59 and got predicate (A), while the Ministry of ATR / BPN scored 62.11 with the title (B) and ranked 52. The rating is a reflection of the performance results that have been done by the Ministry of ATR / BPN not only from the central office but also from all levels of the Ministry of ATR / BPN in the region. This means that the line of the Ministry of ATR / BPN in the region is still a lot of imperfect in applying Performance Based Budgeting (PBB) in its working environment.

Based on the description of these conditions it is necessary to examine the extent to which the implementation of PBB in the budgeting system in the Ministry of Agrarian and Spatial / BPN, especially in the offices in the area. In this study the authors will examine the implementation of performance-based budgeting within the Ministry of ATR / BPN West Nusa Tenggara province. More precisely the research conducted in the Regional Office BPN West Nusa Tenggara Province. The researcher is interested in conducting research on BPN West Nusa Tenggara Regional Office because it is the Satker with the biggest budget ceiling among other work units in West Nusa Tenggara Province. It is also a pilot project within the 
Ministry of ATR / BPN in the province of West Nusa Tenggara in the application policies and regulations including the implementation of performance-based budgeting, so the extent to which the implementation of the field should be studied in depth.

The focus of the research in this research is to see the implementation of Performance Based Budgeting through planning and budgeting, budget realization, performance evaluation, and reporting of budget and performance in the Regional Office of BPN West Nusa Tenggara Province and what are the obstacles / barriers and then find the solution. The purpose of this study is to describe and explain the implementation of performance-based budgeting from planning and budgeting, budget realization, performance evaluation, and budget reporting and performance as well as problems encountered and found solutions.

\section{Literature Review}

\section{New Public Management (NPM)}

The NPM model focuses on performance-oriented public sector management, not policy. The use of the new paradigm has several consequences for the government, including demands for efficiency, cost cutting and tender competition. One model of government in the NPM era is the government model proposed by Osborne and Gaebler (1992) known as the "reinventing government" concept as follows (Mardiasmo, 2009: 79):

1. The catalyst government (focus on providing direction rather than the production of public services),

2. Community-owned government (more empowering communities than serving),

3. Competitive government (encouraging the spirit of competition in the delivery of public services),

4. The mission-driven government (turning the organization driven by the rules into a mission-driven),

5. Result-oriented governments (financing non-inputs),

6. Customer-oriented government (meeting customer needs, not bureaucracy),

7. Entrepreneurial government (able to create income and not just spend),

8. An anticipatory government (trying to prevent rather than cure),

9. The government of decentralization (from hierarchy to participation and work teams), and

10. The government is oriented to market mechanisms (making changes with market mechanisms / incentive systems rather than administrative mechanisms / systems of procedures and coercion).

According to Hood (1991: 4) cited by Hasibuan (2015) that the concept of New Public Management has seven main components, namely:

1. Professional management in the public sector

2. The existence of performance standards and performance measures

3. Greater emphasis on output control and outcomes

4. Solving of units in the public sector

5. Creating competition in the public sector

6. Adoption of management style in the business sector into the public sector

7. Emphasis on discipline and greater savings in resource use.

\section{The Meaning of Performance-Based Budgeting}

Performance is a picture of the achievement of the implementation of an activity / program / policy in realizing the goals, objectives, mission and vision of the organization (Bastian, 2006: 274). Every organizational activity should be measured and expressed in relation to the vision and mission of the organization. Products and services will lose value if the contribution of those products and services is not related to the achievement of the organization's vision and mission.

Budgets can be interpreted as a package of expected revenue and expenditure estimates that are expected to occur in one or more future periods. Public sector budget is a periodic activity and financial plan (usually in the annual period) containing programs and activities and the amount of funds earned (income / income) and required (expenditure / spending) in order to achieve the goals of public organizations (Widyantoro, 2009). According to the Governmental Accounting Standards Board (GASB) the budget definition is: a financial operation plan, which includes estimates of the proposed expenditure, and the expected source of income to finance it within a certain period of time (Bastian, 2006: 164). 
While Budgeting (budgeting) is an activity to allocate limited financial resources to finance organizational spending that tend not unlimited (Arifuddin, 2007). Thus, Performance Based Budgeting (Budgeting Performance Based) is an organizational-oriented budgeting system and is closely related to the organization's Vision, Mission and Strategic Plan. The main feature of Performance Based Budgeting is the budget prepared by considering the relationship between the funding (input) and the expected outcomes, so as to provide information on the effectiveness and efficiency of activities. Robinson and Brumby (2005) as quoted by Cipta (2011) define performance budgeting as a procedure and mechanism intended to strengthen the link between funds provided to public sector entities with the outcomes and / or outputs of these entities through the use of formal performance information in resource allocation decision making.

According to Mardiasmo (2009: 84) the basis of performance-based budgeting is performance achievement, performance indicators, shopping expenditure analysis, standard unit price and minimum service standards. In addition, these performance-based budgets are designed to ensure that the established budgets can be economically, efficiently and effectively utilized, and are also expected to increase accountability in budget utilization in the form of clear outputs and outcomes according to priority. Indirectly the government will be moved to continue to improve and improve the quality of public services.

With a performance approach, the organization will pay more attention to aspects of achievement of performance than just cost savings alone. This approach shifts the budgeting emphasis from previously highly focused on expenditure items to the measured performance of the work program (Nordiawan, 2010: 82)

\section{Principles and Objectives of Performance-Based Budgeting}

According to the Manual for Performance-Based Budgeting (Ministry of Finance of Republic of Indonesia, 2009:13) the principles used in performance-based budgeting include:

1. Performance-oriented Budget Allocation (output and outcome oriented)

The budget allocations drawn up in the work plan and budget documents are intended to gain the most benefit by using efficient resources.

2. Flexibility of budget management to achieve results while maintaining accountability principles (let the manager manages)

The principle describes the flexibility of the manager of the Work Unit (Budget User Authorization) in carrying out the activities to achieve the outcome as planned and responsible for the use of funds and the achievement of the set performance (outcome).

3. Money Follow Function, Function Followed by Structure

The budget allocation to fund an activity is based on the task and function of the work unit according to the intention of its establishment and then the organizational structure that is formed in accordance with the function carried.

Based on the above mentioned principles, the objective of implementing the PBB is expected (Ministry of Finance of Republic of Indonesia, 2009:14):

1. Shows the linkage between funding and performance achievement to be achieved (directly linkages between performance and budget);

2. Improving efficiency and transparency in implementation (operational efficiency);

3. Improving the flexibility and accountability of the unit in carrying out the task and budget management (more flexibility and accountability).

\section{Performance-Based Budgeting Components}

The preparation of a performance-based budget requires three components for each program and activity as described in Article 7 paragraph (2) of Government Regulation no. 21 / 2004 on the preparation of Work Plan and Budget of State Ministries / Institutions in the form of:

1. Performance Indicators

Performance indicators used consist of Key Performance Indicator (KPI) translated as Program Performance Indicator (IKU Program) to assess program performance, Activity Performance Indicators (IK Activities) to assess activity performance, and Output Indicators to assess sub-activity performance. 


\section{Standard Cost}

The cost standard used is the input cost standard at the beginning of the performance-based budget planning stage, and later becomes the output cost standard.

3. Performance Evaluation

Performance evaluation is a process of assessment and disclosure of policy implementation issues to provide feedback for improving the quality of performance, both in terms of efficiency and effectiveness of a program / activity.

\section{Scope of Performance-Based Budgeting}

According to the finance ministry's website, the Scope of Performance-Based Budgeting includes:

1. Determine the Vision and mission (which reflects the organization's strategy), goals, objectives, and targets.

The determination of the vision, mission, goals, objectives, and targets is the first stage that an organization should set and be the highest goal to be achieved so that every performance indicator must be associated with that component.

2. Determining Performance Indicators.

the performance indicators should be those that will be calculated and measured and used as a basis for assessing or viewing the level of performance in both the planning stage, the implementation stage and the post-event stage of completion and benefit. Performance indicators include: Inputs, Outputs, Outcomes, Benefits, and Impacts.

3. Evaluation and decision making on program selection and priorities.

This activity involves the compilation of alternative ranks and then making decisions on programs / activities that are considered a priority given the limited resources.

4. Cost Standard Analysis (ASB)

ASB is the standard cost of a program / activity so that the budget allocation becomes more rational.

\section{Research Methods}

Based on research questions and research objectives, the appropriate approach used in this study is using a qualitative research approach, the research that intends to understand the phenomenon of what is experienced by the subject of research such as behavior, perception, motivation, action, and others holistically by way of descriptions in the form of words and languages in a specific, natural context and by utilizing natural methods (Moleong, 2014: 6). The qualitative research process involves important efforts, such as asking questions and procedures, collecting specific data from participants, analyzing data inductively from specific themes to common themes and interpreting the meaning of the data (Creswell, 2010: 4)

This research uses qualitative approach with phenomenology strategy. Phenomenology is a research strategy in which researchers identify the nature of human experience about a particular phenomenon (Creswell, 2010: 20). Phenomenological research focuses on something experienced in the consciousness of the individual, called intentionality. Intentionality, describes the relationship between the processes that occur in consciousness and the object of concern to the process (Smith, et al., 2009: 12).

The consideration of the phenomenology approach is that the implementation of performance-based budgeting is a social phenomenon composed of awareness with the existence of social interaction between various parties. The experience of informants in implementing performance-based budgeting is what the researchers will try to explore further as to what the implementation is in terms of planning and budgeting, budget realization, performance evaluation, and budget and performance reporting and what are the constraints faced in implementing performance-based budgeting in West Nusa Tenggara Regional Office of $\mathrm{BPN}$, and then look for solutions to the problem.

There are two kinds of data used in this research that is primary data and secondary data. Primary data in this study is data obtained from interviews and observations conducted by researchers, meanwhile secondary data is data obtained from the study of researchers to the documents related. In this research, researchers position themselves as intact participants by showing the role of an observer who is doing 
qualitative observation. Qualitative observation is an observation in which the researcher directly goes to the field to observe the behavior and activities of the individuals in the research location (Creswell, 2010: 267).

Determination of key informants in this study using the technique of "purposive sampling". According Sugiyono (2014: 218) purposive sampling is a technique of retrieving informant data source with certain considerations. These considerations are the people who are considered the most knowledgeable and have the required information in the research area. While the data collection procedure uses field observation, unstructured interviews, and documentation. While testing the validity of the data using source triangulation techniques. According Sugiyono (2014: 274) Triangulation of sources is to test the validity of internal data is done by checking data that has been obtained through several sources. The data that have been analyzed by the researcher so as to produce a conclusion next for the agreement (member check) with some other data sources such. While the data analysis using Miles and Huberman method as presented by Sugiyono (2014: 246-253), that activity in qualitative data analysis consists of three flow of activities, namely data reduction, data presentation, and conclusion.

\section{Results and Discussion}

Regional Office of the National Land Agency is a representative of the Ministry of Agrarian and Spatial / BPN existing at the provincial level that has the task of carrying out government duties in the field of land regionally in accordance with the provisions of legislation that has a Vision: To be an institution capable of realizing land and land for the greatest prosperity of the people, as well as justice and sustainability of the social, national and state system of the Republic of Indonesia. With Mission: Develop and organize land politics and policy to:

1. Increasing people's welfare, creating new sources of people's prosperity, reducing poverty and income gaps, and strengthening food security.

2. Improvement of a more just and dignified common life order in relation to the control, ownership, use and utilization of land (P4T).

3. The realization of a harmonious coexistence of living by addressing various disputes, conflicts and land affairs throughout the country and the arrangement of legal instruments and land management systems so as not to bring about disputes, conflicts and cases in the future.

4. Sustainability of the Indonesian community, nation and state system by providing the widest possible access to future generations of land as a source of community welfare. Strengthen the land institution in accordance with the spirit, spirit, principles and rules contained in the UUPA and the people's aspirations widely.

\section{Understanding the Meanings of Performance-Based Budgeting}

Performance-based budgeting reflects several things. First, the purpose and objective of the request for funds. Second, the cost of the proposed programs in achieving this goal. And third, qualitative data that can measure the achievement and work performed for each program. Budgeting with this performance approach focuses on the efficiency of organizing an activity. An activity can be said to be efficient if the resulting output is greater with the same input, or the resulting output is equal to the fewer inputs. This budget is based not only on what is spent, as is the case with traditional budget systems, but also based on certain goals / plans whose implementation needs to be developed or supported by an adequate budget and the use of such costs should be efficient and effective.

Understanding the meaning of performance-based budgeting by informants shows that budget compilers generally understand the core of the notion of performance-based budgeting. Broadly speaking, the understanding is in accordance with the definition, meaning, and philosophy of performance-based budgeting is the approach of budget preparation with more attention to aspects of performance achievement and benchmarks that can be used to measure performance in the achievement of public service goals and targets (Nordiawan, 2010).

There is a need for continuous socialization on the understanding of the concept of performancebased budgeting which is expected to be a continuous reminder and can later become an individual awareness in applying performance-based budgeting. 


\section{Planning and Arrangement Performance-Based Budgeting}

Performance planning is the basis for performance-based budgeting. Performance indicators are formulated and defined in accordance with the performance information desired by the organization. Performance information contained in performance planning is the basis of performance-based budget allocation. In this Performance-Based Budgeting system, the benefits of performance planning are as follows:

a. Connect strategic planning and operational planning in detail.

b. Assist the achievement of program implementation results.

c. Facilitate the process of measurement and performance appraisal.

d. Assist in setting performance targets.

e. Assist performance monitoring and evaluation

As a vertical agency with a work unit from the top to the district as the smallest work unit, the approach used in planning and budgeting is the bottom-up and top-down approach. Top-down means National Land Agency (BPN) itself already has strategic work programs that are contained in the strategic plan and then downgraded to the office, to the smallest work unit. On the basis of these programs the smallest units make their own work plans. Then bottom-up means the budgeting made from the smallest work units that will eventually be forwarded to the center, while still referring to the strategic plan. However, what happened during the planning stage of this performance, precisely the strategic plan as a reference in preparing the plan and controlling the implementation of programs and activities and in preparing performance reports, has not been made.

\section{Budget Realization}

Budget realization is the process of budget execution based on the approved Ministries budget work plan (RKA-KL), the use of financial resources, control, and the improvement of budget within a period of the fiscal year. RKA-KL itself is an elaboration of the strategic plan Work Program prepared for each one fiscal year as a reference in planning and budget control.

Some responses from interviews regarding budget realization at the regional offices are that in practice the realization is still flexible, there are some activities that say because one thing or another cannot be done, still given the facility of budget revision, which is change name, time of implementation or amount of rupiah from a pre-planned work program. This can happen because the working environment is dynamic.

Implementation of budget is closely related to Standard Operating Procedures (SOP). SOP serves as an operational step guide to complete a task quickly, precisely and effectively, so it is one element that must be determined before implementing Performance Based Budgeting.

Based on the results of the interviews obtained budget realization is still not orderly, but already there are provisions to regulate the implementation of the budget. If there is one thing or another which resulted in an activity being postponed or being upgraded, the relocation and reallocation facility should be the choice for the work unit to revise its budget. But what happens sometimes is a shortcut to use. The facility is ignored. Actual use of budgets from other work unit posts that have not been absorbed, or from the same work unit for different activities that have not been absorbed, become commonplace. The frequent budget revision is due to the discrepancy between planned in the annual work plan (DIPA) and the actual situation in the region.

\section{Performance Evaluation}

Evaluation on the achievement of each activity performance indicator aims to provide further explanation of the things that support the success and failure of the implementation of an activity. Evaluation also aims to determine the achievement of realization, progress and obstacles encountered in order to achieve the mission, to be assessed and studied in order to improve the implementation of programs / activities in the future.

In addition, in performance evaluation, there is also an efficiency analysis by comparing the output with the inputs for both the plan and the realization. This analysis describes the level of efficiency performed by the agency by providing data of output value per unit generated by a particular input. Furthermore, there is also a measure of effectiveness level that describes the level of conformity between the objectives with the 
results, benefits or impacts. Evaluation is also conducted on each performance gap that occurs both on the cause of the gap and the problem-solving strategies that have been and will be implemented. At this stage of the evaluation, the performance achievement has not been evaluated with the strategic plan and the concept of value for money. In addition, the control and evaluation system has not been effective. following:

Some things can be done in performing performance evaluation among others, comparing the

- Real performance with planned performance.

- Real performance with the performance of previous years.

- Performance of an agency with the performance of other institutions that excel in their field or with the performance of the private sector.

- Real performance with performance in other countries or with international standards.

\section{Budget and Performance Reporting}

In government agencies, performance reports are prepared in the form of Performance Accountability Reports within Government Institutions or commonly known as LAKIP. Lakip is one form of accountability as presidential instruction through Presidential Instruction No. 7/1999 on performance accountability of government agencies which is then reaffirmed through LAN decision No. 239 / IX / 6/8/2003 dated March 25, 2003 on guidelines for preparation of accountability report of government agencies.

Regional Office of National Land Agency of West Nusa Tenggara has made a performance report in the form of LAKIP. This performance report is prepared by each work unit and compiled at the level of essay II by the Planning and Financial sub-division. However, what happened during this Regional Office of National Land Agency of West Nusa Tenggara Province has not evaluated the lyrics that have been prepared based on performance achievement.

Based on the above phenomenon, it can be said that the reporting of performance in BPN Regional Office of West Nusa Tenggara Province is still far from expected. Performance-Based Budgeting has not been properly implemented. Planning, implementation, measurement, evaluation and performance reporting have not been properly implemented. There are still processes that are carried out in formality and mere administration. This phenomenon is similar to that found in Rahayu's research, et al (2007) and Widyantoro (2009) where policy changes are only followed by regions at the level of technical change and format, but paradigm changes have not occurred much.

\section{Conclusion}

Based on the results of analysis on the conditions encountered in the study as above, the conclusions can be drawn in this study are as follows:

1. In general, budget managers in BPN Regional Office of West Nusa Tenggara have understood the meaning of Performance Based Budgeting, namely budgeting that is oriented to the output of the resulting performance.

2. Despite understanding the meaning of Performance-Based Budgeting, so far the Regional Office of West Nusa Tenggara BPN has not implemented Performance Based Budgeting properly because:

- Unset and established strategic work unit level plan

- Frequent budget revisions due to incompatibility between annual work plans and actual circumstances

- Control and evaluation system which is still weak

- In terms of reporting performance only to meet formalities and administration.

3. Obstacles found in the implementation of performance-based budgeting in BPN Regional Office of West Nusa Tenggara Province

- There has not yet been drafted and enacted the strategic plan of regional offices as the elaboration of the central strategic plan

- In budget planning not all units can make good budget planning

- Lack of number and low quality of human resources managing planning and budgeting

- Not implemented the reward and punishment system 


\section{Reference}

[1] Arifuddin, Haryanto Sahmuddin. 2007. Public sector accounting. Semarang: Diponegoro University Publishing Agency

[2] Bastian, Indra. 2006. Public sector accounting. Jakarta: Erlangga

[3] Cipta, Hendra. 2011. Analysis of Performance Based Budgeting Application (Performance Based Budgeting) At Local Government (Study Eksploratif At Tanah Datar Government). Padang: Andalas University.

[4] Creswell, John W. 2010. Research Design: Qualitative, Quantitative and Mixed Approaches. Translator: Achmad Fawaid. Pustaka Pelajar: Yogyakarta.

[5] Haryanto, Sahmuddin, Arifuddin. 2007, Public sector accounting. Semarang: Diponegoro University Publishing Agency

[6] Hasibuan, Dini Rahmi. 2015. Analysis of Full Implementation of Government Regulation Number 71 Year 2010 Concerning Accrual Based Accounting Standards (Case in Medan City Government). Medan: University of Northern Sumatra

[7] Hesrini, Elly. 2015. Analysis of Performance-Based Budgeting At Gresik Customs Control and Service Office. e-Jurnal Ilmu Manajemen MAGISTRA Vol. 1 No.1 Februari 2015

[8] Mardiasmo, 2009. Public sector accounting. Penerbit Andi: Yogyakarta.

[9] Menpan. 2015. http://www.menpan.go.id/berita-terkini/120-info-terkini/4173-raporperkembangan-nilai-akuntabilitas-kinerja-k-l-provinsi accessed April 11, 2016

[10] Metrotvnews. 2016. http://ekonomi.metrotvnews.com/makro/5b2MG6nN-minta-anggarandisetujui-legislator-kritisi-kinerja-kementerian-atr accessed June 17, 2016

[11] Ministry of Finance of Republic of Indonesia and BAPPENAS. 2009. Book 2. Guidelines for the Application of Performance-Based Budgeting (PBB). Jakarta.

[12] Moleong, Lexy J. 2014. Qualitative Research Methodology. Rosda: Bandung.

[13] Nordiawan, Deddi dan Ayuningtyas H. 2010. Public sector accounting. Salemba Empat: Jakarta.

[14] Rahayu, Sri., Unti L., dan Didied A. 2007. Phenomenological Study of Regional Budgeting Process (Empirical Evidence from a Regional Device Unit in Jambi Province). Makassar: Simposium Nasional Akuntansi (SNA) X. pp: 1-22

[15] Sancoko, Bambang. 2008. Review of Performance-Based Budgeting in Indonesia. Financial Education and Training Agency, Ministry of Finance of the Republic of Indonesia.

[16] Smith, Jonathan A., Flowers, Paul., and Larkin. Michael. 2009. Interpretative phenomenological analysis: Theory, method and research. Los Angeles, London, New Delhi, Singapore, Washington: Sage.

[17] Solikin, Akhmad. 2006. Merging of Financial Statements and Performance Reports of Government Agencies: Development and Problems. Jurnal Akuntansi Pemerintah, Vol.2 No.2 November 2006.

[18] Sugiyono. 2014. Quantitative Research Methods, Qualitative and R \& D. Alfabeta: Bandung.

[19] Surianti, M. dan Dalimunthe, A.R., 2015. The Implementation of Performance Based Budgeting In Public Sector (Indonesia Case: A Literature Review). Research Journal of Finance and Accounting. Vol.6, No.12, pp:198-211

[20] Utomo, Nugroho Adi. 2007. Performance-Based Budget: Challenges Towards Good Forest Governance. Ministry of Forestry of the Republic of Indonesia.

[21] Viva. 2015. http://politik.news.viva.co.id/news/read/676873-komisi-ii-desak-kementerian-atrmaksimalkan-serapan-anggaran accessed April 11, 2016

[22] Widyantoro, Ari Eko. 2009. Implementation of Performance Based Budgeting: A Phenomenological Review (Case Study at Diponegoro University). Semarang: Diponegoro University 